\title{
Psychological assessment of chronic pain patients: when, how and why refer?*
}

\author{
Avaliação psicológica de pacientes com dor crônica: quando, como e por que encaminhar?
}

José Luiz Dias Siqueira1', Marcia Carla Morete²

${ }^{*}$ Receved from Israelite Hospital Albert Einstein, São Paulo, SP, Brazil.

DOI 10.5935/1806-0013.20140012

\section{ABSTRACT}

BACKGROUND AND OBJECTIVES: Notwithstanding several studies pointing to a relationship between psychological aspects and pain, the scientific literature still lacks articles specifically addressing the psychological assessment process. This study aimed at answering to three questions: Why, when and how to refer painful patients to a psychological assessment? With this, we intend to cooperate with professionals of different areas by offering them guidelines about major indications for psychological assessment, what should be expected from this process and how to effectively refer patients.

CONTENTS: The following databases were searched: Medline, LILACS, Pubmed and Scielo, by crossing the terms "psychology", "pain", "psychology interview" and "psychological tests". In addition, we looked for articles having in the title or abstract the words "psychological assessment" or "psychological evaluation" and "pain" - since the two former terms are not descriptors identified in Health Sciences Descriptors. Studies between 2002 and 2013 were considered, being included only those specifically mentioning psychological assessment, resulting in 11 articles in total.

CONCLUSION: From selected studies, all have pointed to justifications about the importance of psychological assessment of painful patients. As to indications to psychological assessment, seven articles have addressed the subject. The major gap was related to how to refer patients. Only one out of 11 articles has addressed this subject. Further studies may, in the future, better explore this aspect.

Keywords: Pain, Psychological interview, Psychology.

1. Israelite Hospital Albert Einstein, Psychology Area, São Paulo, SP, Brazil.

2. Israelite Hospital Albert Einstein, Nursing Area, São Paulo, SP, Brazil.

Submitted in September 17, 2013.

Accepted for publication in February 13, 2014.

Conflict of interests: None.

Correspondence to:

José Luiz Dias Siqueira

Av. Albert Einstein, 627 - Morumbi

Instituto de Ensino e Pesquisa do Hospital Israelita Albert Einstein

Especialização em Dor

05652-900 São Paulo, SP, Brasil.

E-mail: joseldsiqueira@gmail.com

(C) Sociedade Brasileira para o Estudo da Dor

\section{RESUMO}

JUSTIFICATIVA E OBJETIVOS: Apesar de inúmeros estudos apontarem a relação entre aspectos psicológicos e a experiência dolorosa, a literatura científica ainda carece de artigos a respeito, especificamente, do processo de avaliação psicológica. $\mathrm{O}$ objetivo deste estudo foi obter respostas para três perguntas: Por que, quando e como encaminhar pacientes com dor para uma avaliação psicológica? Com isso pretende-se colaborar com profissionais de diversas áreas no sentido de oferecer-lhes apontamentos sobre as principais indicaçôes para uma avaliação psicológica, o que esperar desse processo e como fazer o encaminhamento de uma maneira eficaz.

CONTEÚDO: Foi realizada uma pesquisa nas bases de dados Medline, LILACS, Pubmed e Scielo, cruzando-se os termos: "psychology", "pain", "psychology interview" e "psychological tests". Além disso, foram buscados artigos que contivessem no título ou no resumo as palavras "psychological assessment" ou "psychological evaluation" e "pain" - já que estes dois primeiros não são descritores identificados nos Descritores em Ciências da Saúde. Foram considerados trabalhos entre 2002 e 2013, sendo incluídos apenas os que se referiam especificamente à avaliação psicológica, resultando em 11 artigos no total.

CONCLUSÁO: Dos estudos selecionados, todos apontavam justificativas sobre a importância da avaliação psicológica do paciente com dor. Quanto a indicaçóes para a avaliação psicológica, sete artigos abordaram o assunto. A grande lacuna se referiu ao modo de se encaminhar o paciente. Apenas um dos 11 artigos abordou esse assunto. Novos estudos podem no futuro explorar melhor esse aspecto.

Descritores: Dor, Entrevista psicológica, Psicologia.

\section{INTRODUCTION}

Traditional biomedical approach started to be further challenged in the second half of last century. Specifically with regard to pain, studies pointed to the need for a model encompassing the complexity of the pain phenomenon. The biopsychosocial perspective closes this gap by confirming the existence of a dynamic relationship among biological changes, psychological status and social context ${ }^{1}$.

The difficulty to accept the multidimensional nature of pain is largely linked to the widespread acceptance of Cartesian principles separating mind from body ${ }^{2}$. Conversely, the biopsycho- 
social approach tries to consider physical, psychological, social and spiritual aspects not separately, but as an integrated whole. As a consequence of biopsychosocial understanding, pain management starts to require interdisciplinary work, counting on the integrated action of professionals of different specialties ${ }^{3}$.

In this sense, pain persisting for a long time has major impact on all domains of life. Several complex conditions associated to chronic pain affect individuals' physical and psychosocial functioning. Among them, there are sleep disorders, loss of appetite, drug dependence, mood disorders, crises of anxiety, fatigue and frustration, which generate numerous consequences for those people, their families, jobs and to the health system ${ }^{4}$.

In addition, several studies show the major role of biopsychosocial factors in triggering chronic pain, in the process of acute pain chronicity and in patients' incapacity. Associated to those issues, one may add cognitive elements, such as patients' beliefs; affective elements, such as anxiety, depression and stress; and behavioral elements such as learning and reinforcement processes $^{1,5-8}$.

The intertwining of body processes and emotion, cognition and interpersonal dynamics explains addressing psychological variables to manage chronic pain?

Psychological assessment is a practice based on scientific method and counts on different resources to promote thorough understanding of the individual. Among major practices of this process there are information collection, psychological tools and different measurements methods to identify specific dimensions of subjects, their environment and the relationship between them ${ }^{10}$. Notwithstanding the increasing importance of Psychology in pain management, professionals of other areas still lack knowledge about the criteria to refer patients to psychological assessment and what can be expected from this process.

With this study we intend to cooperate with professionals of different areas by offering them guidelines about major indications for psychological assessment, what should be expected from this process and how to effectively refer patients. For such, scientific articles published in the last 11 years about the subject were reviewed.

\section{CONTENTS}

We looked for studies published from 2002 to 2013, in English, Portuguese and Spanish in LILACS, Medline, SciElo and PubMed databases, crossing the following descriptors: "psychology", "pain”, "psychological interview" and "psychological tests". In addition, we looked for articles having in the title or abstract the expressions "psychological assessment", "psychological evaluation" and "pain", since the two former terms are not identified among Health Sciences Descriptors. Major inclusion criteria were direct reference to psychological assessment processes.

In total, 11 articles were selected addressing psychological assessment in different contexts. Articles analysis tried to understand how each of these articles answered to one or more of the following questions:

1. When to refer patients to psychological assessment?

2. Why refer patients to psychological assessment?

3. How to refer patients to psychological assessment?

Table 1 shows analyzed articles, their authors, major subjects addressed and which questions, from the three above, could be answered as from the reading of each text.

\section{When to refer patients to psychological assessment?}

The prospective cohort study on low back pain tried to identify signs and symptoms which would prompt clinicians to the need for psychological assessment of patients with chronic low back pain. A rehabilitation team and a group of psychologists have evaluated 229 patients. By crossing data evaluated by the physiotherapists of the team and those evaluated by psychologists, the study arrived at four variables which could prompt generalists to the importance of additional psychological assessment: daily use of analgesics, presence of Waddell signs, high pain drawing test scores and absence of directional preference ${ }^{11}$.

According to authors, Waddell signs are a set of 8 physical signs which may indicate non-organic or psychological components of chronic low back pain. The pain drawing test used divides a human body diagram into 45 anatomic areas which, if marked

Table 1. Description of selected texts

\begin{tabular}{|c|c|c|c|c|c|}
\hline Authors & Types of studies & Subjects & 1 & 2 & 3 \\
\hline Apeldoorn et al. ${ }^{11}$ & Cohort prospective study & Low back pain & $x$ & $x$ & \\
\hline Castro et al. ${ }^{12}$ & Comparative study & Orofacial pain & & $x$ & \\
\hline White ${ }^{13}$ & Review article & Chest pain & $x$ & $x$ & $x$ \\
\hline Rosen $^{14}$ & Review article & Tension-type headache & & $x$ & \\
\hline Zhang et al. ${ }^{15}$ & Transversal study & Pelvic pain & & $x$ & \\
\hline Rivera et al. ${ }^{16}$ & Prospective study & Pain interventional medicine & $x$ & $x$ & \\
\hline Koestler $^{17}$ & Review article & Hand pain & $x$ & $x$ & \\
\hline Cruz \& Sardá ${ }^{18}$ & Transversal study & Low back pain, lumbosciatic pain & & $x$ & \\
\hline Turk et al. ${ }^{19}$ & Review article & Neuropathic pain & $x$ & $x$ & \\
\hline Beltrutti \& Lamberto 20 & Review article & Radiofrequency & $x$ & $x$ & \\
\hline Beltrutti et al. ${ }^{21}$ & Review article & Spinal cord stimulation & $x$ & $x$ & \\
\hline
\end{tabular}


by patients as painful, receive scores ${ }^{11}$.

The article on hand pain has shown several points to which clinicians should be attentive to identify the need for psychological assessment: low adhesion to treatment, resistance in taking the responsibility for their own health care, avoidance behaviors, catastrophizing, emotional reactions, exaggerated painful behaviors and expressions of guilt, anger and hopelessness. In addition, in the presence of suicide ideation, psychotic symptoms or drug abuse, psychological assessment becomes mandatory ${ }^{17}$.

The study on chest pain has shown that, in practice, major reason for referring patients to psychological assessment is, in general, not poor adhesion to treatment. Other aspects often leading clinicians to make such referral are: behavioral (smoking, inactivity) and emotional (depression, anxiety, anger) risk factors, in addition to coping difficulties ${ }^{13}$.

The article on neuropathic pain has determined six situations in which psychological assessment is indicated: 1) when incapacity goes well beyond what is expected from patients as from clinical findings; 2) when patients exaggeratedly demand health services; 3) when patients insist in looking for treatments and exams which are not indicated; 4) when patients have significant distress; 5) when patients show behaviors of drug dependence or poor adhesion to proposed treatment; 6) before interventional procedures, such as spinal cord stimulation ${ }^{19}$.

With regard to this latter item, two articles show the critical role of psychological assessment just before interventional procedures. The article on spinal cord stimulation has concluded that the process of determining whether patients are fit for the procedure should necessarily include the evaluation of patients' psychosocial characteristics ${ }^{20}$. In the article on radiofrequency, authors have reached similar conclusions ${ }^{21}$.

In this context, two major objectives are shown with regard to psychological assessment: 1) determining the presence of psychological and social characteristics which may increase the likelihood of the benefit of the procedure, and 2) helping physicians identifying patients for whom such treatment could result in uncertainty, failure or medical-legal consequences. Very often, in spite of the success of the treatment, patients are unable to perceive a significant change in their status. This "failure" is closely related to the way each patient experiences pain. This aspect should be taken into consideration through a careful psychological assessment before any interventional procedure ${ }^{21}$.

\section{Why refer patients to psychological assessment?}

From 11 evaluated articles, all have addressed justifications for psychological assessment: 10 tried to justify why to refer chronic pain patients to evaluation by a psychologist and one tried to justify why not to refer them.

A prospective cohort study tried to analyze whether interventional physicians were able to identify anxiety and depression using a brief interview and a questionnaire based on the Diagnostic and Statistical Manual of Mental Disorders, $4^{\text {th }}$ edition (DSMIV). The study has concluded that such professionals were successful in identifying these two conditions in 100 patients of an interventional pain center ${ }^{12}$. Authors have justified that, when not referring patients to psychologists or psychiatrics, there are time and money savings.

One Brazilian study has identified in 55 patients with low back pain and lumbosciatic pain a strong presence of emotional changes which could interfere or cooperate with the manifestation or perpetuation of such diseases, which would justify the need for psychological assessments ${ }^{18}$. A Chinese study on pelvic pain has concluded that the management of such patients is much more adequate when it is performed as from a multidisciplinary approach including routine psychological assessment ${ }^{15}$.

A different Brazilian study has compared several aspects among 30 patients of a hospital: 15 with trigeminal neuralgia and 15 with temporomandibular disorders. Notwithstanding the first group having more severe and limiting pain, there have been no significant differences with regard to complaints and levels of depression and anxiety, which suggests that pain intensity may not be directly related to affective aspects. For the authors, this fact justifies the need for careful psychological assessment of facial pain patients ${ }^{12}$.

Article on hand pain explains that, when psychological assessment early identifies complicating psychological and behavioral factors in patients with such condition, this helps more adequate interventions and improves management results ${ }^{17}$.

\section{How to refer patients to psychological assessment?}

The article on chest pain shows that many clinicians have difficulties in referring patients to a psychologist so it is critical to explain patients about the reasons why psychological assessment is important. According to the article, patients are more receptive to referral when this is introduced as part of an essential routine for treatment results. Explanations are essential since anxious patients may think that the physician suspects that their pain is not real, or that they have a mental disease causing the symptoms ${ }^{13}$.

\section{CONCLUSION}

Several articles address psychological pain aspects, however few mention psychological assessment. The lack of the term "psychological assessment” among Health Sciences Descriptors makes difficult a search by the subject.

From 11 evaluated articles, 10 intended to give justifications for the psychological assessment of patients with pain, among them: understanding the influence of emotions on pain; identifying stressors and coping styles; evaluating patients' expectations; identifying difficulties and pointing targets for interventions.

One article has stated that interventional physicians are able to detect anxiety and depression in pain patients without the help of a mental health professional. However, other articles have shown how broad might be a psychological assessment of pain patients, going well beyond the identification of anxiety and depression. Seven articles have shown referral criteria for psychological assessment, among them: poor adhesion to treatment, avoidance, catastrophizing, guilt, anger, distress, hopelessness, suicide ideation and before interventional procedures.

From all articles, only one has mentioned the way to refer patients to psychological assessment ${ }^{13}$. Further studies should better explore this fundamental aspect of working with pain pa- 
tients, because the way in which patients are referred very often determines the acceptance of the work of the psychologist and also patients' adhesion to the treatment as a whole.

\section{REFERENCES}

1. Sardá JJ, Nicholas MK, Pimenta CA, Asghari A. Preditores biopsicossociais de dor, incapacidade e depressão em pacientes brasileiros com dor crônica. Rev Dor. 2012;13(2):111-8.

2. Loeser JD. Part II: Evaluation of the pain patient, Introduction. In: Loeser JD, Butler SH, Chapman RC, Turk DC, (editors). Bonica's Management of Pain. $3^{\text {rd }}$ ed. Philadelphia (PA): Lippincott Williams \& Wilkins Publishers; 2001. 43-6p.

3. Almeida FF, Costa AL, Doca FN, Turra V. Experiência de dor e variáveis psicossociais: o estado da arte no Brasil. Temas em Psicologia. 2010;18(2):367-76.

4. Garven A, Brady S, Wood S, Hattfield M, Bestard J, Korngut L, et al. The impact of enrollment in a specialized interdisciplinary neuropathic pain clinic. Pain Res Manag. 2011;16(3):159-68

5. Turk DC, Okifuji A. Psychological factors in chronic pain: evolution and revolution. J Consult Clin Psychol. 2002;70(3):678-90.

6. Andrasik F, Flor H, Turk DC. An expanded view of psychological aspects in head pain: the biopsychosocial model. Neurol Sci. 2005;26(Suppl2):S87-91.

7. Eccleston C, Palermo TM, de Williams AC, Lewandowski A, Morley S, Fisher E, et al. Psychological therapies for the management of chronic and recurrent pain in children and adolescents. Cochrane Database Syst Rev. 2012;12:CD003968.

8. Linton SJ. A review of psychological risk factors in back and neck pain. Spine (Phila Pa 1976). 2000;25(9):1148-56.

9. Silva DS, Rocha EP, Vandenberghe L. Tratamento psicológico em grupo para dor crônica. Temas em Psicologia. 2010;18(2):335-43.
10. Capitấo CG, Scortegagna SA, Baptista MN. A importância da avaliaçáo psicológica na saúde. Avaliaçăo Psicológica. 2005;4(1):75-4.

11. Apeldoorn AT, Bosselaar H, Ostelo RW, Blom-Luberti T, van der Ploeg T, et al. Identification of patients with chronic low back pain who might benefit from additional psychological assessment. Clin J Pain. 2012;28(1):23-31.

12. Castro AR, Siqueira SR, Perissinotti DM, Siqueira JT. Psychological evaluation and cope with trigeminal neuralgia and temporomandibular disorder. Arq Neuropsiquiatr 2008;66(3B):716-9.

13. White KS. Assessment and treatment of psychological causes of chest pain. Med Clin North Am. 2010;94(2):291-318.

14. Rosen NL. Psychological issues in the evaluation and treatment of tension-type headache. Curr Pain Headache Rep. 2012;16(6):545-53.

15. Zhang G, Bai W, Xu T, Wang X. A preliminary evaluation of the psychometric profiles in Chinese men with chronic prostatitis/chronic pelvic pain syndrome. Chin Med J. 2011;124(4):514-8.

16. Rivera JJ, Singh V, Fellows B, Pampati V, Damron KS, McManus CD. Reliability of psychological evaluation in chronic pain in an interventional pain management setting. Pain Physician. 2005;8(4):375-83.

17. Koestler AJ. Psychological perspective on hand injury and pain. J Hand Ther 2010;23(2):199-211.

18. Cruz RM, Sardá JJ. Diagnóstico de aspectos emocionais associados à lombalgia e à lombociática. Avaliação Psicológica, 2003;1:29-33.

19. Turk DC, Audette J, Levy R, Mackey SC, Stanos S. Assessment and treatment of psychosocial comorbidities in patients with neuropathic pain. Mayo Clin Proc. 2010;85(3 Suppl):S42-50.

20. Beltrutti D, Lamberto A. Psychological assessment of candidates for radiofrequency treatment. Pain Pract. 2002;2(3):201-5

21. Beltrutti D, Lamberto A, Barolat G, Bruehl SP, Doleys D, Krames E, et al. The psychological assessment of candidates for spinal cord stimulation for chronic pain management. Pain Pract. 2004;4(3):204-21. 